\author{
Tiarma Isi Naibaho \& Ully Irma Maulina Hanafiah \\ Universitas Telkom \\ tiarnaibaho6694@gmail.com \\ ullyrmaulinafia@telkomuniversity.ac.id
}

\title{
ANALISA SIRKULASI RUANG GERAK PENGGUNA PADA AREA BACA DI PERPUSTAKAAN UNIVERSITAS SWASTA Studi kasus: Perpustakaan Learning Center, Telkom University dan Perpustakaan Universitas Parahyangan
}

\begin{abstract}
Abstrak: Perpustakaan diartikan sebagai sebuah ruangan atau gedung yang digunakan untuk menyimpan buku dan terbitan lainnya yang biasanya disimpan menurut tata susunan tertentu yang digunakan pembaca dan bukan untuk dijual (Sulistyo, Basuki: 1991). Sebagai fasilitas umum, perpustakaan banyak dikunjungi terutama mahasiswa sehingga menyebabkan banyaknya pengguna perpustakaan yang melakukan aktivitas bersama di dalamnya yang mempengaruhi kenyamanan setiap pengguna. Oleh karena itu dibutuhkan sirkulasi ruang gerak/jarak bersih agar mengurangi persinggungan antar pengguna untuk meningkatkan kenyamanan dan konsentrasi saat membaca di area baca. Namun sirkulasi ruang gerak di area baca perpustakaan Learning Center dinilai masih sangat kurang, hal ini dapat dilihat dari jarak peletakan antar rak buku yang menyebabkan persinggungan antar pengguna satu dengan yang lainnya, jarak rak buku dengan meja baca yang mengganggu sirkulasi ruang gerak pengguna perpustakaan, jarak antar kursi di area diskusi yang sempit sehingga mengganggu sirkulasi jalan pengguna lain dan pengguna yang duduk di belakang meja diskusi tersebut. Untuk mendapatkan sirkulasi ruang gerak yang ideal perlu diketahui ukuran manusia dan aktivitas yang dilakukan di area ruang baca tersebut. Oleh karena itu dilakukan penelitian untuk mengetahui dan mendalami lebih lanjut sirkulasi ruang gerak pengguna perpustakaan yang baik dan tepat dengan pertimbangan antropometrik dan ergonomi serta dampak dari sirkulasi ruang gerak yang kurang mempertimbangkan standar antropometrik dan ergonomi terhadap pengguna perpustakaan.
\end{abstract}

Kata kunci: perpustakaan, sirkulasi, ruang gerak, kenyamanan, antropometrik, ergonomi.

\begin{abstract}
Library is defined as a room or a building used to store books and other publications that usually stored according to specific arrangements that used by reader and not for sale (Sulistyo, Basuki: 1991). As public facilities, mainly students visited the librar that causing the number of library users who do activities together in it which influence the comfort of each user. Therefore it takes the circulation space / clearances in order to reduce the interconnections among users to increase the comfort and concentration while reading in the reading area. But the circulation space in the reading area of the library Learning Center have been insufficient, it can be seen from a distance of laying between bookshelves that causes the intersection between users with each other, the distance bookshelf with reading table that interfere with the circulation space for library users, the distance between the seats in the narrow area of discussion that disrupts the circulation of the other users and users who sit behind a desk the discussion. To get the circulation space ideal human need to know the size and the activities conducted in the reading room area. Therefore, to investigate and explore more circulation space for library users is good and right with anthropometric and ergonomic considerations and the impact of the circulation space that is less expensive standard anthropometric and ergonomics of the user library.
\end{abstract}

Keyword: library, circulation, space, comfort, anthropometry, ergonomics. 


\section{Pendahuluan}

Saat ini, perpustakaan merupakan bagian dari kebutuhan manusia yang harus dipenuhi dalam kegiatan studinya, terutama mahasiswa, pelajar dan kelompok lainnya dalam menunjang aktivitas mereka. Perpustakaan adalah lembaga yang salah satu kegiatannya adalah memberikan layanan peminjaman koleksi bahan pustaka baik untuk dibaca ditempat atau untuk dibawa pulang. Berdasarkan IFLA (Internasional Federation of Library Association), perpustakaan perguruan tinggi berperan dalam upaya untuk mengumpulkan, memelihara, menyimpan, mengatur, mengawetkan dan mendaya gunakan bahan pustakanya untuk menunjang pendidikan/pengajaran, penelitian dan pengabdian masyarakat.[1] Oleh karena itu, perpustakaan menjadi fasilitas umum yang diwajibkan ada di setiap universitas dan tempat yang paling sering dikunjungi oleh mahasiswa.

Telkom University sebagai salah satu universitas swasta di Bandung juga memiliki perpustakaan di beberapa fakultas, namun yang terbesar dan terlengkap berada di gedung Learning Center. Learning Center merupakan pusat pembelajaran yang berdiri di atas tanah seluas $5000 \mathrm{~m}^{2}$ dan terdiri dari 5 lantai yaitu lantai dasar yang menyediakan fasilitas belajar 24 jam, lantai 2 sebagai tempat pameran pendidikan sedangkan ruang perpustakaan berada di lantai 3 dan 4. Universitas Katolik Parahyangan (UNPAR) juga memiliki beberapa perpustakaan yaitu perpustakaan fakultas filsafat, perpustakaan pascasarjana, perpustakaan program studi D-3 Manajemen, dan perpustakaan untuk Program Studi S1 yang berada di Gedung 9 lantai 2 dan 4 Jalan Ciumbeluit No. 94, bandung. Perpustakaan ini memiliki beberapa fasilitas seperti ruang baca, layanan fotokopi dan ruang loker.

Sebagai salah satu jenis ruang publik, perpustakaan Learning Center dan Perpustakaan UNPAR menjadi tempat yang paling banyak dan sering dikunjungi karena koleksi dan fasilitasnya yang lebih lengkap dan lebih banyak. Sehingga menyebabkan banyaknya pengguna perpustakaan yang melakukan aktivitas di dalamnya yang mempengaruhi kenyamanan setiap pengguna.

Sebagai sarana pendidikan dan sarana belajar bagi masyarakat, perpustakaan juga dituntut untuk dapat memberikan kepuasan pada pengguna melalui pelayanan dan interior. Lancaster (1997) menyatakan bahwa kepuasan pengguna terhadap layanan perpustakaan salah satunya ditentukan oleh ruangan dan peralatan penunjang tertata dengan baik dan nyaman. Dalam lingkungan interior mengenai hal yang bersangkutan dengan kenyamanan dan kepuasan pengguna, maka rancangan yang tanggap terhadap dimensi manusia dan ukuran tubuh sangatlah diperlukan.

Penggunaan fasilitas umum menyebabkan banyaknya area yang menjadi zona aktivitas bersama yang dirasa mengganggu kenyamanan pengguna. Seperti jarak peletakan antar rak buku yang menyebabkan persinggungan antar pengguna satu dengan yang lainnya, jarak rak buku dengan meja baca yang mengganggu sirkulasi ruang gerak pengguna perpustakaan, jarak antar kursi di area diskusi yang sempit sehingga mengganggu sirkulasi jalan pengguna lain dan pengguna yang duduk di belakang meja diskusi tersebut seta kurangnya pertimbanganpertimbangan antropometrik mengenai sirkulasi ruang gerak menjadi masalah utama dari ruang perpustakaan ini. Dari permasalahan-permasalahan tersebut maka dapat dirumuskan masalah sebagai berikut:

- Bagaimana tata peletakan antar rak buku yang satu dengan yang lainnya di ruang baca perpustakaan?

- Bagaimana jarak peletakan rak buku dengan meja baca pada ruang perpustakaan? 
- Bagaimana perbandingan sirkulasi ruang gerak di ruang perpustakaan dengan sirkulasi ruang gerak dengan pertimbangan antropometrik dan ergonomi?

- Apa dampak dari sirkulasi ruang gerak yang kurang mempertimbangkan standar antropometrik dan ergonomi?

Dengan adanya permasalahan-permasalahan tersebut maka penelitian ini dilakukan dengan tujuan untuk menganalisis, mengetahui dan mendalami lebih lanjut tentang sirkulasi ruang gerak pengguna perpustakaan yang baik dan tepat dengan pertimbangan antropometrik dan ergonomi. Ruang lingkup penelitian ini berada di area ruang baca perpustakaan di lantai 3 Learning Center dan ruang baca di lantai 2 perpustakaan UNPAR dengan batasan penelitian analisis perbandingan sirkulasi ruang gerak (jarak bersih) pengguna perpustakaan dengan sirkulasi ruang gerak dengan pertimbangan antropometrik dan ergonomi.

\section{Landasan Teori}

\subsection{Sirkulasi Ruang Gerak (Jarak Bersih)}

Dalam desain interior, sirkulasi merupakan bagian yang sangat penting yang harus diperhatikan dan direncanakan. Prinsip utama dalam penataan sirkulasi adalah memahami pola aktivitas pengguna yang ada dalam ruangan. Menurut Logi Tofani (2011) dalam laporan tugas akhirnya, menyebutkan pada dasarnya sirkulasi dapat dibagi menjadi 3 berdasarkan fungsinya yaitu sirkulasi kendaraan, sirkulasi barang dan yang akan dibahas pada penelitian ini, sirkulasi manusia. Ciri-ciri dari sirkulasi manusia yaitu kelonggaran dan fleksibel dalam bergerak, berkecepatan rendah dan sesuai dengan skala manusia (Tofani, 2011). Skala manusia yang sering digunakan adalah skala yang ada di buku Data Arsitek dan Human Dimension.

Menurut Fruin, zona personal yang nyaman didasarkan atas zona perlindungan tubuh yang diperluas sampai diameter 42 inci atau $106,7 \mathrm{~cm}$, pada posisi ini seseorang dapat melewati jarak antara dua orang yang berdiri bersampingan dengan posisi menyamping. Sedangkan zona sirkulasi, Fruin memperluas zona perlindungan tubuh sampai dengan diameter 48 inci atau $121,9 \mathrm{~cm}$. Fruin menyatakan bahwa pada zona perlindungan tubuh yang terbentuk seluas 0,93 $-1,21 \mathrm{~m}^{2}$ per orang, memungkinkan terjadinya suatu sirkulasi tanpa mengganggu orang lain.

\subsection{Sirkulasi Ruang Gerak di Area Baca \& Rak Buku}

Berdasarkan buku Libraries and Learning Resource Centres (Brian Edwards dan Biddy Fisher)[2] dalam perencanaan perpustakaan universitas memiliki beberapa standar ruang untuk area baca, antar lain:

- Satu ruang pembaca untuk setiap 3-4 pelajar masing-masing sekitar $1 \mathrm{~m}^{2} / \mathrm{orang}$

- 8-10 buku berada pada rak buku di ruang baca, 10-12 pada tumpukan terbuka, 12-15 pada tumpukan tertutup, dan 40-60 pada gudang

- Area sirkulasi sebesar $20 \%$ dari total luas ruang perpustakaan

Rak buku merupakan hal vital dalam perpustakaan, sehingga penempatan rak buku yang satu dengan yang lain juga harus diperhatikan jaraknya. Tujuannya agar pengguna dapat dengan mudah mengambil koleksi atai buku di rak tanpa bersinggungan dengan pengguna yang lain. Jarak yang baik untuk penempatan rak-rak koleksi khususnya rak buku adalah 1,5 m-2,3 m sehingga dapat dilalui dua sampai tiga orang tanpa bersinggungan (Neufert, 2002:4).[3] 
Tabel 1. Ukuran dan jarak minimal yang dianjurkan untuk rak lantai untuk akses pengguna perpustakaan.

\begin{tabular}{|c|c|c|c|}
\hline No. & Parameter & Gambar & Ukuran \\
\hline 1. & $\begin{array}{l}\text { Luas lantai untuk lorong dengan } 1 \text { pengguna mendorong troli dan } \\
\text { pengguna lain berdiri dengan posisi tubuh menyamping. }\end{array}$ & & $114 \mathrm{~cm}$ \\
\hline 2. & $\begin{array}{l}\text { Luas lantai untuk lorong dengan } 1 \text { pengguna berjongkok dengan } \\
\text { menghadap ke rak dan pengguna lain melintas. }\end{array}$ & & $117 \mathrm{~cm}$ \\
\hline 3. & Luas lantai untuk lorong dengan 2 pengguna melintas. & & $122 \mathrm{~cm}$ \\
\hline 4. & $\begin{array}{l}\text { Luas lantai untuk lorong dengan } 1 \text { pengguna duduk menghadap rak } \\
\text { sedangkan pengguna lain melintas. }\end{array}$ & & $132 \mathrm{~cm}$ \\
\hline 5. & $\begin{array}{l}\text { Luas lantai untuk lorong dengan } 1 \text { pengguna berdiri menghadap ke } \\
\text { rak sedangkan pengguna lain melintas dengan mendorong troli. }\end{array}$ & & $137 \mathrm{~cm}$ \\
\hline 6. & $\begin{array}{l}\text { Luas lantai untuk lorong dengan } 1 \text { pengguna menunduk sedangkan } \\
\text { pengguna lain melintas. }\end{array}$ & & $147 \mathrm{~cm}$ \\
\hline
\end{tabular}

Tabel 2. Ukuran kebutuhan luas lantai untuk suatu pekerjaan

\begin{tabular}{|c|l|c|c|}
\hline No. & \multicolumn{1}{|c|}{ Parameter } & Ukuran \\
\hline 1. & Luas lantai untuk kursi dengan penggunanya & $81 \mathrm{~cm}$ \\
\hline 2. & $\begin{array}{l}\text { Luas lantai saat pengguna berdiri dan menjulurkan } \\
\text { tangannya ke depan }\end{array}$ & $86 \mathrm{~cm}$ \\
\hline 3. & $\begin{array}{l}\text { Luas lantai saat pengguna dengan badan menghadap ke } \\
\text { rak }\end{array}$ & $\begin{array}{l}\text { Luas lantai untuk pengguna ketika menggunakan kursi } \\
\text { saat berdiri dari kursi dan menggeser }\end{array}$ & $81 \mathrm{~cm}$ \\
\hline
\end{tabular}




\begin{tabular}{|c|l|l|l|}
\hline 5. & $\begin{array}{l}\text { Luas lantai untuk 2 pengguna dengan aktivitas pengguna } \\
1 \text { mengarah ke meja dan pengguna satunya melintas }\end{array}$ & $173 \mathrm{~cm}$ \\
\hline 6. & \begin{tabular}{l} 
Luas lantai untuk 1 pengguna berdiri leluasa \\
\hline 7.
\end{tabular} & $\begin{array}{l}\text { Luas lantai untuk 1 pengguna berdiri menyamping } \\
\text { setengah berjongkok }\end{array}$ & $33 \mathrm{~cm}$ \\
\hline 8. & $\begin{array}{l}\text { Luas lantai untuk pengguna duduk di lantai dengan pantat } \\
\text { diangkat }\end{array}$ & $61 \mathrm{~cm}$ \\
\hline
\end{tabular}

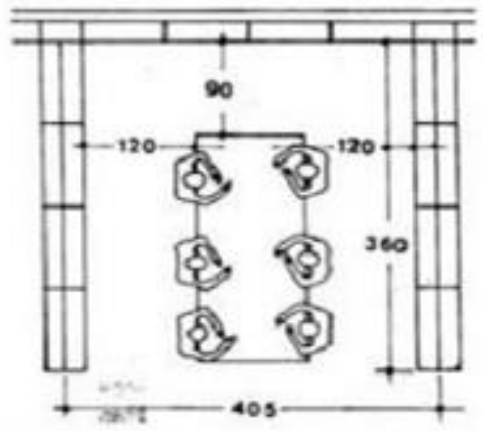

Gambar 1. Kebutuhan ruang untuk suatu pekerjaan (Sumber: Somintardja, 1977)

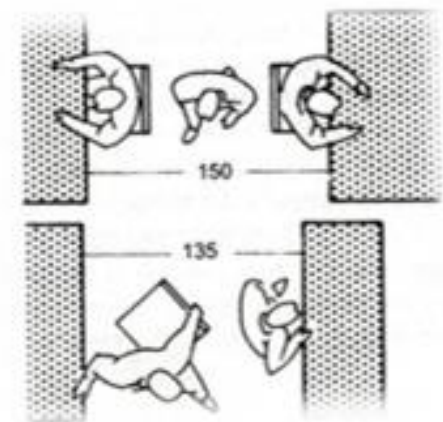

Gambar 3. Ruang gerak minimum di dalam jangkauan ruang baca

(Sumber: Neufert, 2002)

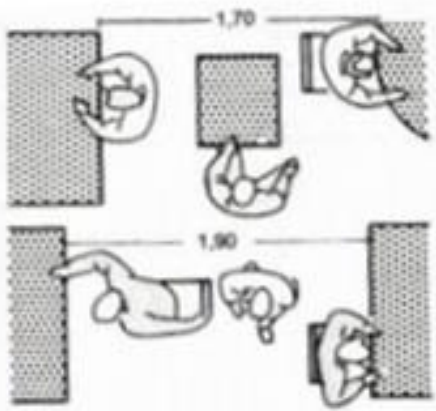

Gambar 2. Lalu lintas pergerakan antara posisi duduk dan berdiri

(Sumber: Neufert, 2002)

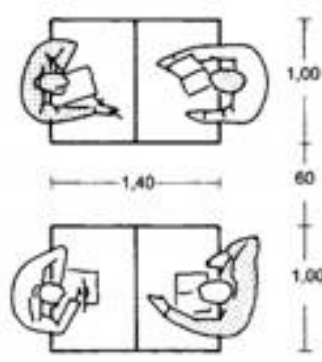

(2) Jarak minimum artar megan

Gambar 4. Jarak minimum antar meja (Sumber: Neufert, 2002 
Tabel 3. Ukuran kebutuhan luas lantai untuk pekerjaan di perpustakaan

\begin{tabular}{|c|l|c|}
\hline No. & \multicolumn{1}{|c|}{ Parameter } & Ukuran \\
\hline 1. & Luas lantai untuk jarak dari dinding ke meja arah memanjang & $120 \mathrm{~cm}$ \\
\hline 2. & Luas lantai untuk jarak dari dinding ke meja arah memendek & $90 \mathrm{~cm}$ \\
\hline 3. & Panjang meja untuk kapasitas 6 pengguna & $270 \mathrm{~cm}$ \\
\hline 4. & Jarak antar meja ke meja (meja persegi) & $150 \mathrm{~cm}$ \\
\hline 5. & Jarak antar meja ke meja (meja bundar) & $170 \mathrm{~cm}$ \\
\hline 6. & Dua meja yang berhadapan & $140 \mathrm{~cm}$ \\
\hline 7. & Jarak meja ke meja lainnya & $60 \mathrm{~cm}$ \\
\hline 8. & Meja untuk pengguna & $100 \mathrm{~cm}$ \\
\hline
\end{tabular}

\section{Metode Penelitian}

Metode yang digunakan dalam meneliti adalah metode deskripsi komparatif yaitu meneliti kondisi obyek ilmiah dengan cara membandingkan dan mendeskripsikan data yang didapat melalui observasi dengan data literatur. Dalam melakukan penelitian ini diperlukan data-data dan informasi yang lengkap, relevan serta jelas. Untuk mengumpulkan bahan-bahan serta mendapatkan data yang berhubungan langsung dengan penelitian dilakukanlah peninjauan langsung yang meliputi:

- Observasi dan pengukuran

Observasi dilakukan di dua lokasi yaitu, area baca perpustakaan yang terletak di lantai 3 Learning Center, yang beralamat di Jalan Telekomunikasi No. 1 Kawasan Telkom University, Dayeuh Kolot, Bandung dan area baca perpustakaan Universitas Katolik Parahyangan Gedung 9 lantai 2 yang berlokasi di Jalan Ciumbeluit No. 94, Bandung. Kegiatan yang dilakukan yaitu mengamati dan mendokumentasikan keadaan di area objek penelitian, serta melakukan pengukuran jarak antar meja baca, jarak antar rak dan meja baca dengan rak sehingga diketahui sirkulasi ruang gerak/jarak bersih pengguna pada area baca perpustakaan. Observasi dilakukan dengan tujuan untuk memperoleh data-data dan informasi untuk menganalisis objek penelitian.

- Wawancara

Wawancara dilakukan dengan beberapa pengguna perpustakaan yaitu mahasiswa Telkom University dan Unpar dengan mengajukan pertanyaan-pertanyaan tentang sirkulasi ruang gerak pada area baca perpustakaan sehingga diketahui sumber permasalahan yang menyebabkan ketidaknyamanan pada sirkulasi ruang gerak.

- Literatur

Data literatur yang digunakan pada penelitian ini diambil dari buku, jurnal, tugas akhir dan internet tentang sirkulasi ruang gerak manusia khususnya di perpustakaan. 


\section{Hasil}

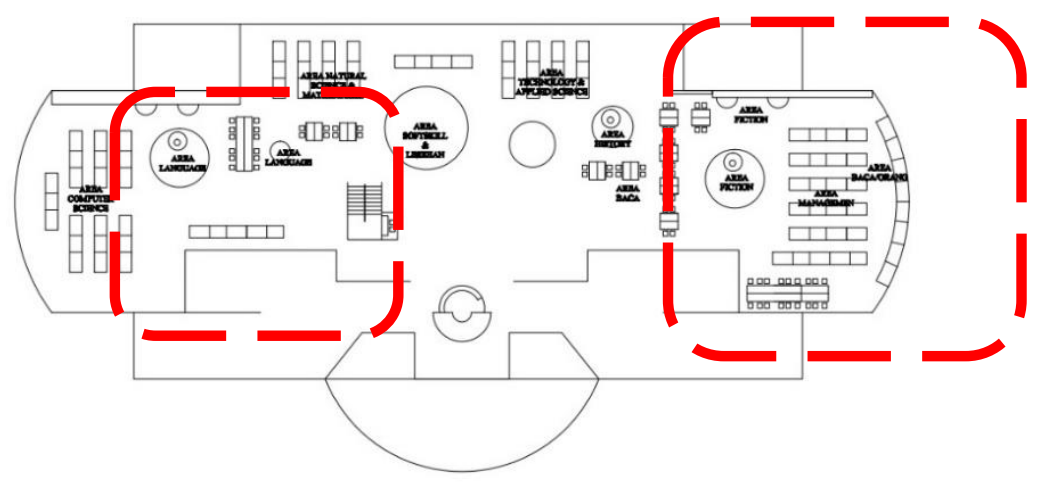

Gambar 5. Layout perpustakaan Learning Center

Berdasarkan hasil observasi, wawancara dan literatur yang terkumpul, maka diperoleh evaluasi untuk sirkulasi ruang gerak pengguna sebagi berikut:

Tabel 4. Sirkulasi Ruang Gerak Pada Area Baca

\begin{tabular}{|c|c|c|c|}
\hline No & $\begin{array}{c}\text { Ruang Baca } \\
\begin{array}{c}\text { Perpustakaan Telkom } \\
\text { University }\end{array} \\
\end{array}$ & Standar Perpustakaan & $\begin{array}{c}\text { Ruang Baca } \\
\text { Perpustakaan UNPAR }\end{array}$ \\
\hline 1. & $\begin{array}{l}\text { koleksi Fiction } \\
\text { Jarak antar meja baca } \\
\text { pada area koleksi buku } \\
\text { Fiction yaitu 80 cm } \\
\text { sementara jarak kursi } \\
\text { saat duduk ke rak } \\
\text { dinding pada area } \\
\text { koleksi buku Fiction } \\
\text { yaitu 35 cm. Dengan } \\
\text { jarak tersebut } \\
\text { mengakibatkan } \\
\text { pengguna lain ttidak } \\
\text { dapat melintas ketika } \\
\text { area tersebut digunakan } \\
\text { pengguna lain sehingga }\end{array}$ & $\begin{array}{l}\text { (Sumber: Neufert, 2002) } \\
\text { - Pada area baca aktivitas yang } \\
\text { terjadi seperti duduk, } \\
\text { membaca, membawa troli } \\
\text { dibutuhkan ruang gerak } \\
\text { minimum di dalam } \\
\text { jangkauan antar meja saat } \\
\text { posisi duduk yaitu 135-150 } \\
\text { cm, sedangkan jarak antar } \\
\text { meja minimum untuk lalu } \\
\text { lintas pergerakan saat posisi } \\
\text { duduk dan berdiri yaitu 170- } \\
190 \text { cm. }\end{array}$ & $\begin{array}{l}\text { Gambar } 8 \text {. Meja baca pada } \\
\text { area baca umum } \\
\text { Jarak antar meja baca } \\
\text { pada area baca umum } \\
\text { dengan adanya kursi } \\
\text { adalah } 90 \mathrm{~cm} \text {, sementara } \\
\text { jarak meja ke rak buku } \\
\text { dengan adanya kursi } \\
\text { adalah } 120 \mathrm{~cm} \text {. Jarak } \\
\text { tersebut } \\
\text { memperhatikan standar. }\end{array}$ \\
\hline
\end{tabular}




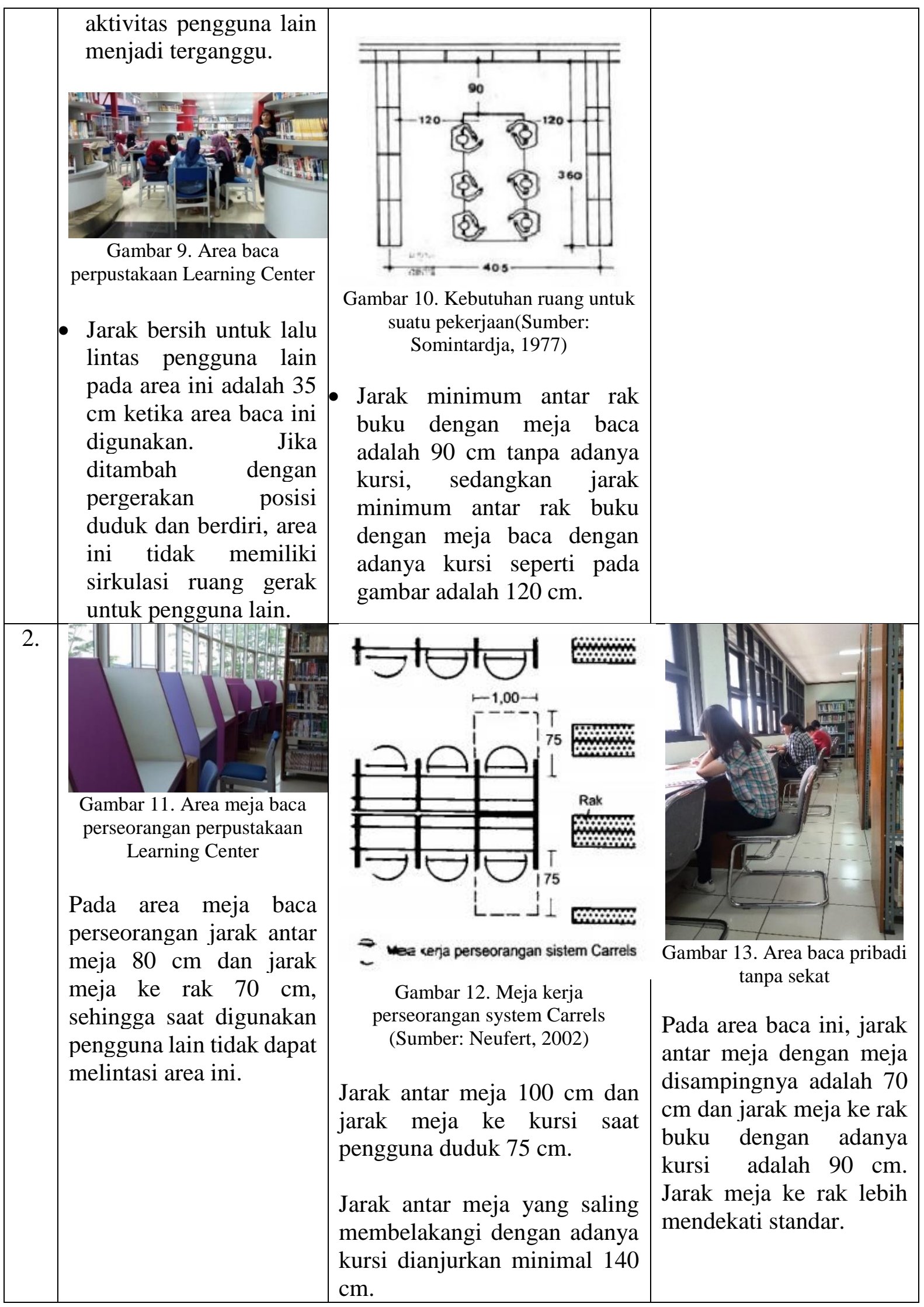




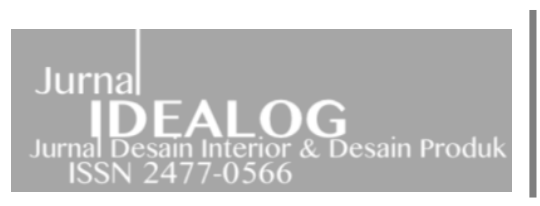

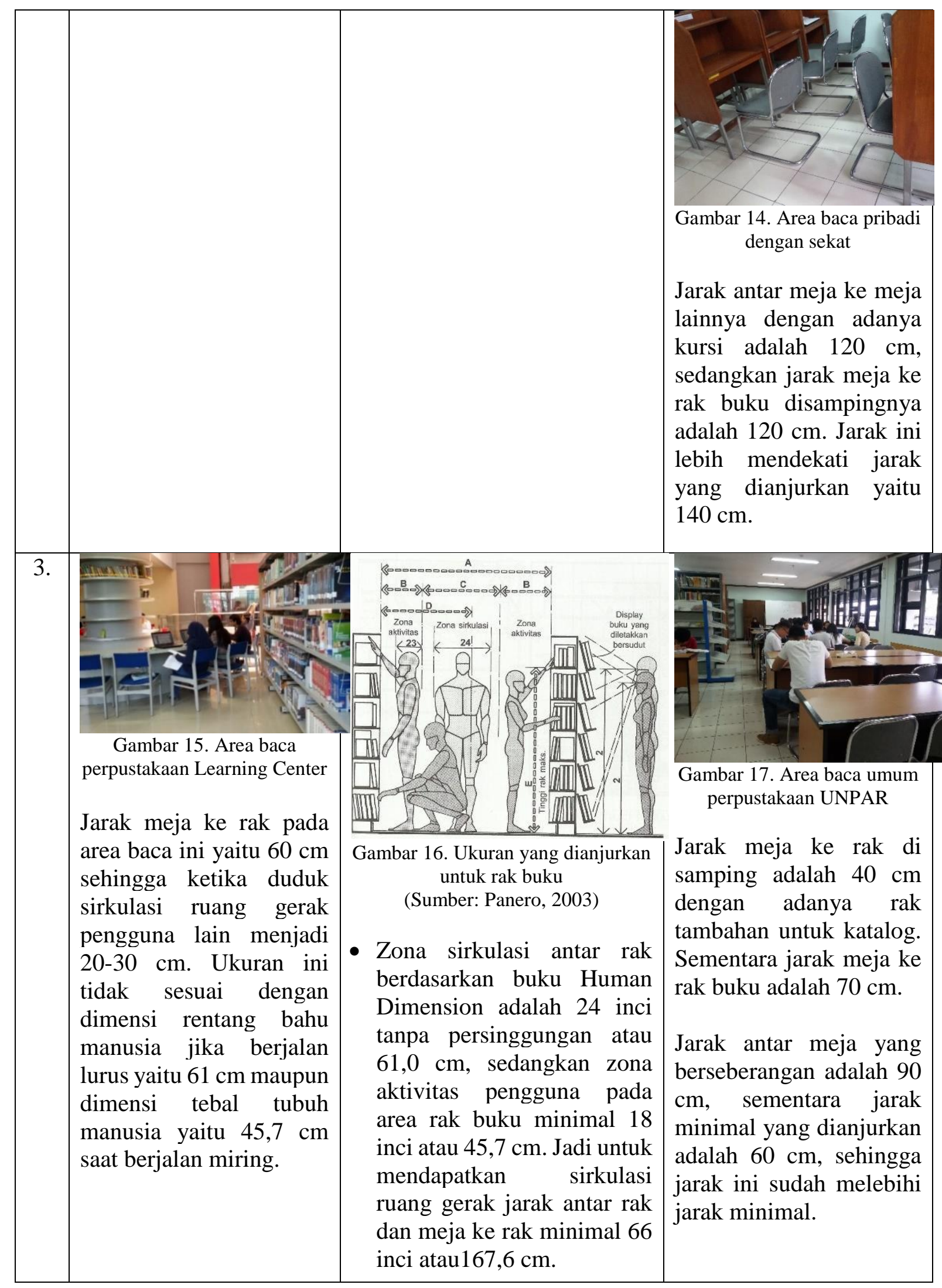




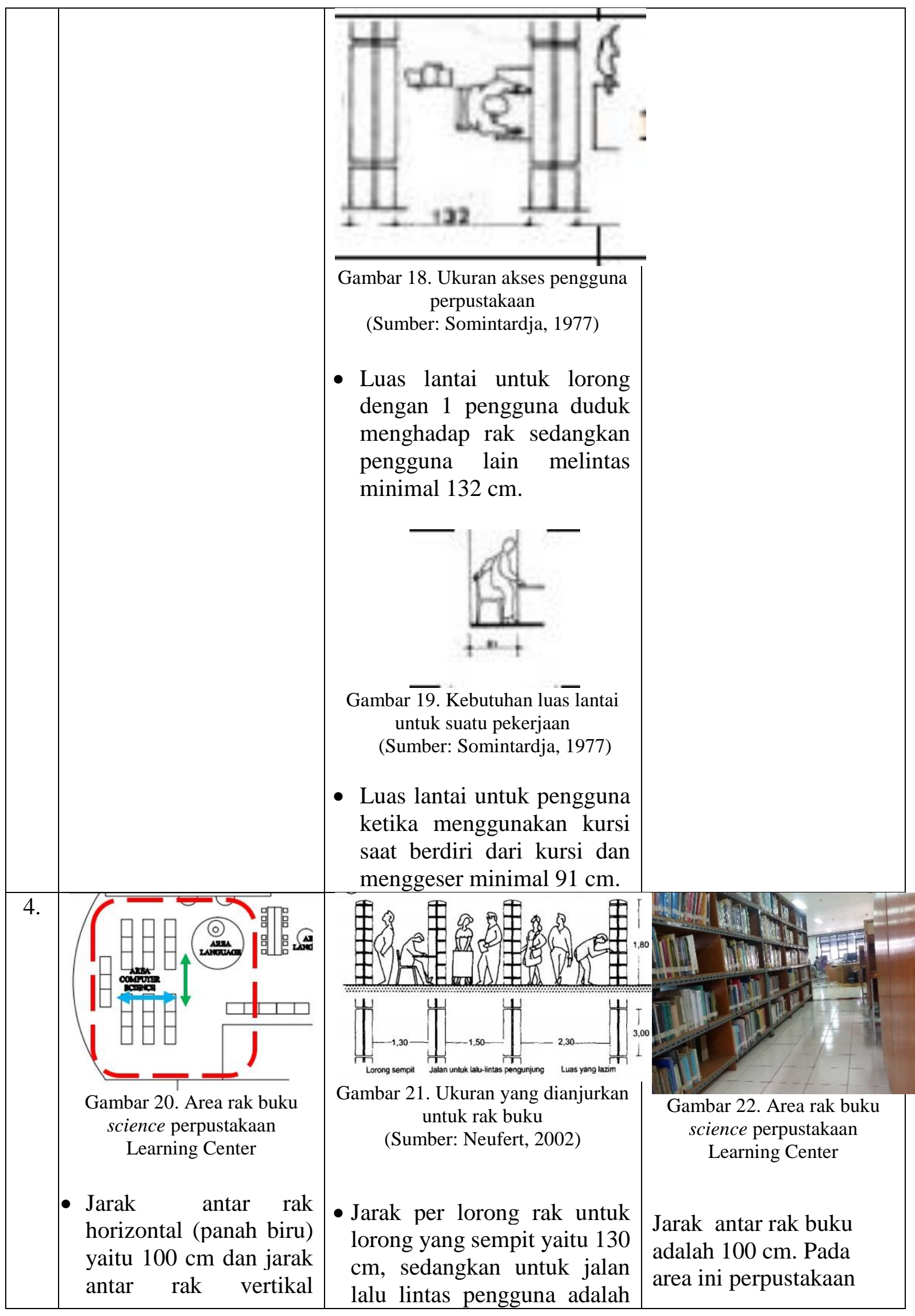




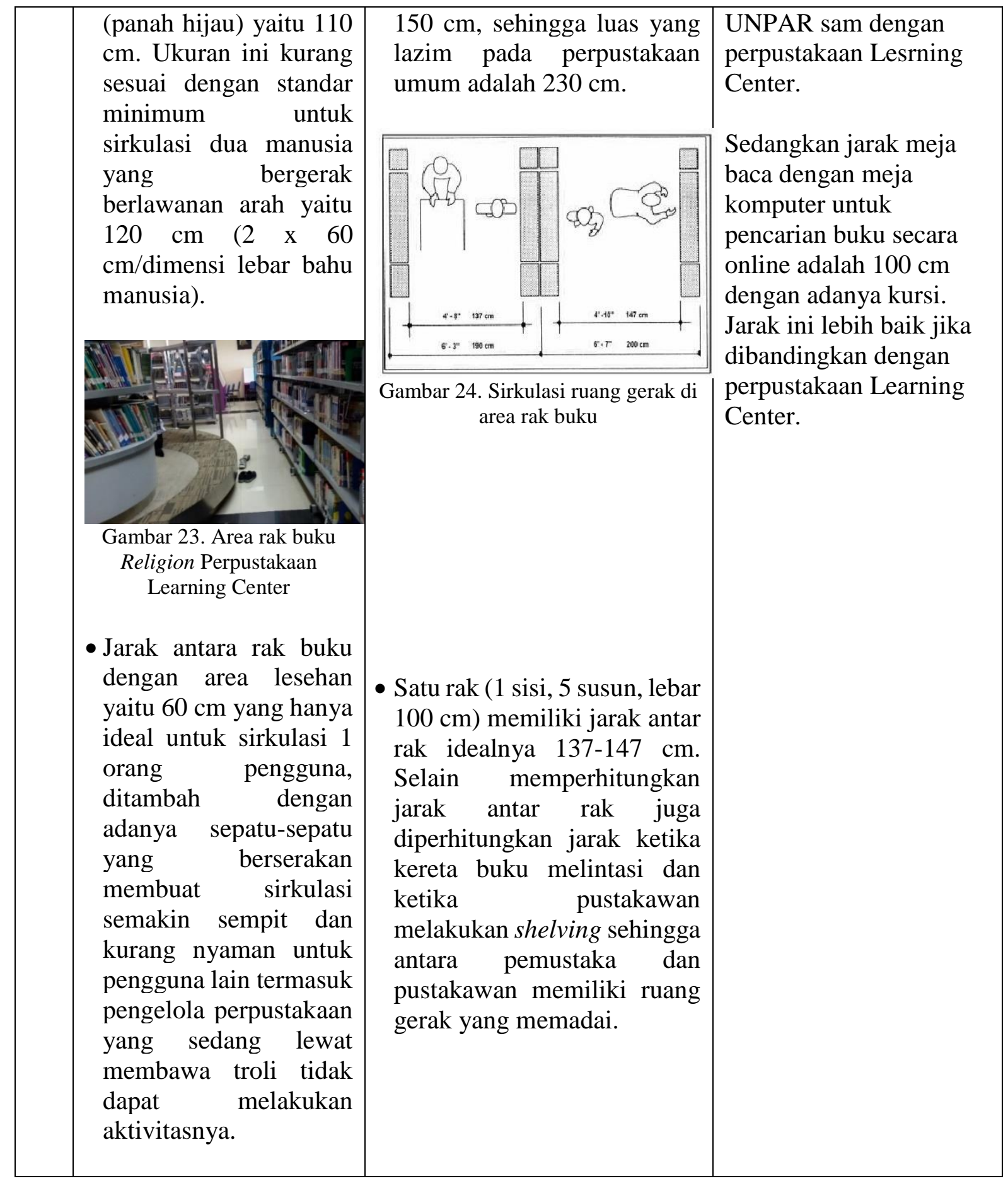

Berdasarkan tabel di atas dapat dilihat bahwa sirkulasi ruang gerak pada area baca perpustakaan Learning Center ditinjau dari jarak tata letak furnitur dinilai masih kurang baik dan belum memenuhi standar yang mempertimbangkan ergonomi dan antropometrik. Sedangkan sirkulasi ruang gerak pada area baca perustakaan UNPAR dinilai lebih baik dari perpustakaan Learning Center. Setelah melakukan proses pengukuran jarak sirkulasi ruang gerak pada perpustakaan UNPAR beberapa area seperti area baca umum sudah sesuai dengan standar. Sementara beberapa area seperti area baca pribadi tanpa sekat dan area baca pribadi 
dengan sekat sudah mendekati standar yang ada. Area rak buku pada kedua perpustakaan sama yaitu $100 \mathrm{~cm}$, sementara jarak yang dianjurkan minimal $130 \mathrm{~cm}$.

Untuk mendapatkan kenyamanan saat membaca dengan mengurangi persinggungan antar pengguna yang sedang membaca dengan pengguna yang melintas, jarak bersih untuk 1 orang yang melintas minimal $60 \mathrm{~cm}$ yang didasarkan pada ukuran lebar bahu manusia dan untuk jarak bersih lalu lintas pergerakan saat posisi duduk dan berdiri dengan adanya pengguna lain yang melintas yaitu minimal $120 \mathrm{~cm}$. Namun karena pengukuran antropometrik penting, yang digunakan haruslah rentang tubuh, bukan rentang bahu dan data "rata-rata" karena ukuran tersebut tidak mengakomodasikan mayoritas populasi manusia (Panero : 1979).[4] Oleh karena itu untuk mendapatkan dimensi jarak bersih yang ideal, tubuh manusia harus digunakan sebagai penambah ukuran dasar dan tubuh manusia yang lebih besar. Karena jika jarak bersih yang didapat dari pengukuran dimensi tubuh manusia yang lebih besar maka tentunya jarak bersih tersebut dapat berlaku pada tubuh manusia yang lebih kecil sehingga jarak ideal untuk sirkulasi ruang gerak dengan adanya kursi yang saling membelakangi seperti pada Gambar 6 dapat dirata-ratakan dari 150-190 cm. Sehingga sentuhan yang terjadi pada area baca saat beraktivitas seperti duduk dan menggeser kursi, membaca, membawa troli, melintas dapat dihindari dan memungkinkan untuk dua orang berjalan bersisian maupun berlawan arah dengan nyaman tanpa terjadinya kontak tubuh.

Sedangkan sirkulasi untuk area lorong rak buku jarak minimum antar rak adalah $130 \mathrm{~cm}$ untuk lalu lintas 2 pengguna. Sedangkan jarak yang ideal dengan 2 pengguna yang beraktivitas dan 1 pengguna yang melintas adalah $170-230 \mathrm{~cm}$. Untuk mendapatkan jarak yang ideal dilakukan penghitungan dengan pertimbangan aktivitas di area lorong rak buku yang tidak hanya melintas saja, namun terdapat aktivitas lain menguras zona sirkulasi seperti kegiatan saat menuduk dan jongkok untuk melihat koleksi buku yang berada di rak bagian bawah sementara pengguna lain sedang melintas dengan membawa troli. Seperti teori Panero tentang jarak bersih sebagai pertimbangan utama yaitu dengan memilih dimensi tubuh paling besar, sama halnya dengan menentukan jarak ideal dengan cara pemilihan aktivitas yang paling banyak memakai ruang dalam hal ini pengguna yang melintasi lorong rak buku dengan membawa troli dan pengguna lain melintas dengan arah berlawanan dengan adanya 1 pengguna yang sedang berdiri menyamping menghadap rak. Dari perhitungan jarak untuk aktivitas tersebut didapatkanlah hasil $230 \mathrm{~cm}$ yang dinilai cukup ideal untuk jarak antar rak buku.

Sementara jarak ideal dari meja baca yang berdekatan dengan rak buku yaitu luas lantai untuk lorong dengan 1 pengguna duduk menghadap rak sedangkan pengguna lain melintas, jarak minimal $132 \mathrm{~cm}$ ditambah dengan luas lantai untuk pengguna ketika menggunakan kursi saat berdiri dari kursi dan menggeser minimal $91 \mathrm{~cm}$. Maka jarak ideal antar meja baca dengan rak buku adalah $223 \mathrm{~cm}$ yang dapat dibulatkan menjadi $130 \mathrm{~cm}$. 


\section{Kesimpulan}

Dari pengumpulan data dan hasil analisa dapat disimpulkan bahwa sirkulasi ruang gerak pengguna pada area baca dan rak buku perpustakaan UNPAR lebih baik dari pada sirkulasi ruang gerak area baca perpustakaan Learning Center. Jarak sirkulasi ruang gerak area baca perpustakaan Learning Center, Telkom University belum mendekat jarak sirkulasi ruang gerak yang sesuai dengan standar yang mempertimbangkan faktor antropometri dan ergonomi. Sementara sirkulasi ruang gerak pengguna pada area baca dan rak buku pada perpustakaan UNPAR lebih mendekati jarak sirkulasi ruang gerak yang sesuai dengan standar.

Berdasarkan hasil kajian di atas maka dapat diperoleh dampak yang dapat ditimbulkan oleh sirkulasi ruang gerak yang kurang mempertimbangkan faktor antropometri dan ergonomi, seperti berikut:

- Kurangnya sirkulasi ruang gerak menimbulkan ketidaknyamanan pada pengunjung perpustakaan karena terjadinya persinggungan dan kontak fisik antar pengguna.

- Ketidaknyamanan yang terjadi di area baca membuat konsentrasi saat membaca menjadi terganggu karena setiap pengguna lain melintasi area sirkulasi yang kurang, pembaca harus menoleh dan menarik kursinya.

Ketidaknyamanan juga dirasakan poleh pengguna yang akan melintasi area tersebut untuk menuju area berikutnya sehingga lebih memilih mengambil jalan lain yang lumayan menyita waktu. Sesuai dengan Teori Panero tentang penggunaan rentang tubuh, bukan rentang bahu dan data "rata-rata" karena tidak mengakomodasikan mayoritas populasi manusia, dapat disimpulkan bahwa untuk mendapatkan sirkulasi ruang gerak yang baik perancang haruslah memahami dan mengetahui terlebih dahulu dimensi tubuh pengguna dan pola aktivitas pengguna yang ada di dalam ruangan atau area tersebut.

\section{Daftar Pustaka}

[1] Basuki, Sulistyo.2003. Pengantar Ilmu Perpustakaan. Jakarta : Universitas Terbuka.

[2] Edwards, Brian. 2009. Libraries and Learning Resource Centres, 2nd Edition. Oxford : Elsevier.

[3] Neufert, Ernst. 2002. Data Arsitek, Jilid 1 Edisi Kedua. Jakarta : Erlangga.

[4] Panero, Julius \& Zelnik, Martin. 2003. Human Dimension \& Interior Space. Jakarta : Erlangga.

[5] Rohidi, Tjetjep Rohendi. 2011. Metodologi Penelitian Seni. Semarang : Cipta Prima Nusantara.

[6] Dwi Pratiwi, Niken. 2015. Tinjauan tentang Ergonomi dan Penataan Interior Perpustakaan di SMK Negeri 2 Depok Sleman, Tugas Akhir Skripsi. Tersedia: http://eprints.uny.ac.id/17073/1/Skripsi_Niken\%20Dwi\%20Pratiwi.pdf. Diakses 23 November 2015, pukul 22.53.

[7] Anonim. 2011. Perpustakaan Ergonomis: Pendekatan Aspek Standar Gedung dan Mebelair Perpustakaan.

Tersedia: https://id.scribd.com/doc/76443090/PERPUSTAKAAN-ERGONOMIS. Diakses 23 November 2015, pukul 23.09. 
[8] Surya, Roberta Zulfhi, dkk. 2013. Penggunaan Data Antropometri dalam Evaluasi Ergonomi pada Tempat Duduk Penumpang Speed Boat Rute Tembilahan - Kuala Enok Kab. Indragiri Hilir Riau. Jurnal Ergonomi. Vol. 2 No.1 (2013) 4-8. 